\title{
IMPLEMENTASI KEBIJAKAN PENGELOLAAN INVENTARIS BARANG BERGERAK MILIK DAERAH DI LINGKUNGAN PEMERINTAH KOTA PALANGKARAYA
}

\author{
Implementation of Policy for Management of Goods Inventory with Regional Ownership \\ in the Palangkaraya City Government Environment
}

\section{Muhamad Yusuf Kobota}

Universitas Muhammadiyah

Palangkaraya, Palangka Raya, Central

Kalimantan, Indonesia

email: yusuf.quratayun@gmail.com

\begin{abstract}
Abstrak
Penelitian ini bertujuan ini bertujuan untuk mengakaji implementasi kebijakan pengelolaan inventaris barang bergrak milik daerah di lingkungan Pemerintah Kota Palangka Raya. Focus penelitian diarahkan pada upaya untuk menjawab pertanyaan penelitian bagaimana Implementasi kebijakan pengelolaan inventaris bergerak milik daerah dilingkungan Pemerintah Kota Palangka Raya. Metode Penelitian yang digunakan dalam penelitian ini adalah deksriftif kualitatif dengan data primer diperoleh dari hasil observasi,wawancara, dan dokumentasi terhadap para Kepala SKPD, kepala Unit Pelaksana teknis SKPD dan Pegawai Pengurus, Penyimpan Barang Milik Daerah Kota Palangka Raya.

Hasil penelitian menunjukan bahwa : I)Impelementasi kebijakan pengelolaan inventaris bergerak milik Kota Palangka Raya belum berjalan sebagaimana mestinya yang dominan disebabkan/dipengaruhi oleg faktor komunikai, dan disposisi, sementara faktor sumber daya dan struktur birokrasi juga berperan namun tidak dominan. 2)Pelanggaran terhadap kebijakan tentang pengelolaan inventaris barang bergerak milik daerah yang paling sering terjadi adalah barang bergerak milik daerah kota Palangka Raya dibawa-pakai tanpa prosedur seharusnnya baik saat mutasi ataupun saat purna tugas.
\end{abstract}

Kata Kunci:

Implementasi

Kebijakan

Pengelolaan

Inventaris

BBMD

\section{Keywords:}

Implementation

Policy

Management

Inventory

BBMD

\section{Accepted}

January 2015

\section{Published}

April 2015

\begin{abstract}
This study aims to assess the implementation of the management policies for regional goods belonging to the region within the Palangka Raya City Government. The research focus is directed at efforts to answer research questions on how the implementation of moving inventory management policies belongs to the area of the Palangka Raya City Government. The research method used in this study is qualitative descriptive with primary data obtained from the results of observations, interviews, and documentation of the heads of SKPD, heads of SKPD Technical Implementation Units and Management Officers, Regional Property Storage of the City of Palangka Raya.

The results showed that: I) The implementation of the moving inventory management policy belonging to Palangka Raya City has not been running as it should have been dominantly caused/influenced by communic factors, and dispositions, while resource factors and bureaucratic structures also played a role but were not dominant. 2) The most common violation of the policy regarding the management of movable property belonging to the region is that movable property belonging to the Palangka Raya city area is carried out without procedures, either at the time of transfer or at full time.
\end{abstract}

\section{PENDAHULUAN}

Aset daerah merupakan sumber daya penting bagi Pemerintah Daerah Sebagai penopang utama dalam rangka menyususn laporan neraca pemerintah. Oleh karena itu, penting bagi Pemerintah Daerah untuk dapat mengelola aset secara memadai, akurat dan memiliki database yang kredibel. Dalam pengelolaan aset, Pemerintah Daerah harus menggunakan pertimbangan aspek. Perencaaan kebutuhan dan penggaraan, pengadaaan, penerimaan, penyimpanan dan penyaluran, penggunaan, penatausahaan, pemanfaatan atau penggunaan, pemeliharanaan, penilaian, penghapusan, pemindah tanganan, pembinaan, pengawasan dan pengendalian, pembiayaan dan tuntutan ganti rugi agar aset daerah mampu memberikan kontribusi optimal bagi pemerintah 
daerah yang bersangkutab sehingga arah pembanguan di bidnag pengelolaan aset daerah dapat terintegrasi dan terprogram dengan baik.

Melihat pentingnnya pengelolaan aset daera ini maka pemerintah mengeluarkan Peraturan Pemerintah Nomor 06 Tahun 206 dan disempurnakan dengen Peraturan Pemerintah Nomor 38 Tahun 2008 tentang Pengeloaan Aset Daerah, Peraturan Menteri Dalam Negeri Nomor 17 Nomor 2007 tentang pedoman tehnis pengelolaan barang milik neraga/daerah, Peraturan Menteri Keuangan Nomo 96 Tahun 2007 Tentang Tata Cara Peleksanaan Pengelolaan Barang Milik Negara Dan Peraturan Daerah Kota Palangka Raya Nomor 13 Tahun 201 I Tantang Pedoman Teknis Pengelolaan Braang Milik Daerah.

Aset pemerintah kota Palangka Raya memiliki potensi nilai yang sangat material dan memiliki kontribusi besar dalam mendukung pelaksanaan tugas pemerintah daerah dalam aspek pelayanan tugas pemerintah daerah dalam aspek pelayanan kepada masyarakat. Tututan Good Governance dan transparansi reformasi bdiang keuangan negara termasuk didalamnnya mencakup bidang pengelolaan barnag milik negera/daerah, aset negara/daerah yang diatur dala Undang-Undangn Nomor I Tahun 2004 dinyatakan bahwa pemerintah wajib melakukan pengamanan terhadap barang milik daerah (Bimtek,20I2). Dari hasil observasi penelitian ditemukan fenomena ada indikator ketidakharmonisan reuglasi yang terpisha-pisah terkait dengan pencatatan dan pelaporan aset, serta pengaturan lemahnnya sisa komunikasi dalam struktur birokrasi, disposisi sikap perilaku aspek sumber daya terdapat kurang pemahaman persamaan persepsi dalam hal pengelolaan barang milik daerah.

Berdasarkan fenomen di lapngan, barang/aset inventaris terdaftar dalam penatausahaan di buku inventaris, akan tetapi buktifisik di lapangan barnag inventaris tersebut tidak diketahui keberadaanya karena dibawa PNS saat mutasi pindah tugas ke tempat inventaris intansi yang baru artinya brang inventaris tersbut tidak sedang dalam penguasaan pengguna barang. Fenomena lain sebalikny ada pencatatan dalam buku inventaris atau pencatatan dalam kartu inventaris atau pencatatan dalam kartu inventaris brang (KIB B) di satuan perangkat daerh namun fisiknnya sudah tidak ada dalam pengguasan pengguna barang karena barang inventaris dibaw ikut saat PNS mutasi dan terdapat barang inventaris yang masih dalam proses barangnnya sudah dibawa. Berdasarkan latar belakang tersebut diatas, mendorong penulis melakukan penelitian dengan judul Impelementasi Kebijakan Pengelolaan Inventaris Bergerak Milik Daerah di Lingkungan Pemerintah Kota Palangka Raya.

\section{METODOLOGI}

Tipe Penelitian ini menggunakan pendekatan kualitatif dimana metode penelitian yang digunakan dalam penelitian ini adalah dekskriftif kualitatif. Metode yang digunakan unutk menjawab persoalan apa dan mengapa, makna suatu fenomena atau gejala ditafsirkan oleh peneliti bukan subjek yang diteliti. Dalam pengumpulan data maka dilakukan dengan observasi, wawancara, dan dokumentasi terhadap para SKPD, Kepala Unit Pelaksana SKPD, dan Pegawai Pengurus, penyimpan barang milik daerah Kota Palangka Raya.

\section{HASIL DAN PEMBAHASAN}

Berdasarkan hasil penelitian dilapangan
tentang Impelementasi Kebijakan Pengelolaan
Inventaris Barang Bergerak Milik Daerah Di
Lingkungan Pemerintah Kota Palangka Raya, yaitu :

I. Komunikasi

Hasil menunjukan bahwa sebenarnya selalu diupayakan untuk mengkomunikasikan suatu kebijakan baik dari pemerintah pusat maupun daerah kepada pelaksanaan kebijakan sehingga pelaksanaan kebijakan memiliki kesamaan persepsi 
dalam hal kebijakan yang dilaksanakannya sehingga tujuan dari dibuatnya kebijakan tersebut dapat tecapai. Adapun upaya mengokuminikasikan ini dilkukan melalui sosialisasi-sosialisasi serta bimbingan-bimbingan teknis tentang kebijakan yang akan dilaksankan.

Meskipun pada prinsipnya upaya untuk mengkomunikasikan kebijakan selalu dilakukan namun dapat dikatakan belum maksimal, karena pelaksanaan sosialisasi setiap tahun hanya dianggarkan untuk satu kali sehingga masih ada beberapa pelaksanaan di lapangan yang masih tidak melaksanakan kebijakan sesuai ketentuan yang telah ditentukan. Misalanya saja pada kasus mutasi barang yang non prosedural, seandainya kebijakan dapat dikomunikasikan dengan baik sehingga para pegawai yang mendapatkan pinjaman kendaraan dinas memahami bahw seharusnya mutasi barang jadi bukan hanya barang/kendaraanya saja yang dibawa tetapi berikut dokumen mutasinya.

Hal ini didasarkan pada ungkapan Kepala Bidang Aset BPKAD Kota Palangka Raya (Arice Sandrayanthi, SAP.,M.Si) Fakta terdapat masih kurangnya pemahaman aparatur dalam sudut pandang penapsiran impelementasi isi dari PERDA Nomor 13 Tahun 2006 dan terdapat masih kurangnya atauran-aturan (literatur) lain yang berkaitan dengan tata kelola inventaris aset, selama ini masih belum dibuat khsusnya peraturan walikota yang mengatur secara spesifik mengenai tata cara mutasi barang inventaris bergerak, penghapusan barang inventaris bergerak, tata cara DUM/Penjualan inventaris bergerak.

Faktor komunikais sangat berpengaruh terhadap penerimaan kebijakan oleh kelompok sasaran, sehingga kualitas komunikasi akan mempengaruhi dalam mencapai efektivitas implementasi kebijakan publik.
2. Disposisi

Disposisi merupakan salah satu faktor yang mempunyai konsekuensi penting bagi implementasi kebijakan yang efektif. Jika para pelaksana mempunyai kecenderungan atau sikap positif atau adanya dukungan terhadap implementasi kebijakan maka terdapat kemungkinan yang besar implementasi kebijakan akan terlaksana sesuai dengan keputusan awal.

Mengenai disposisi ini, peneliti menemukan suatu kasus khususnya dalam penjualan barang milik daerah (DUM). Asa kendaraan dinas yang DUM tanpa prosedur yang lazim, yang tanpa pemberitahuan kepada petugas pengurus dan penyimpanan barang tiba-tiba saja seorang pegawai menyatakan bahwa kendaraan dinas sudah di DUM dengan menunjukan memo dari oknum pejabat yang menyatakan bahwa kendaraan dinas sudah di DUM hal inilah yang disebut peneliti sebagai dilema ketidakberdayaan pengurus dan penyimpan barang untuk menegakan kebijakan dan peraturan yang berlaku karena adanya disposisi negatif dari pejabat yang berwenang.

3. Sumber Daya

a. Staf

Staf merupakan sumber daya utama dalam impelentasi kebijakan. Sumber daya yang dimiliki oleh pemerintah daerah Kota Palangka Raya dapat dikatakan cukup memadai yang dapat dilihat dari jumlah aparatur dari 64 orang aparatur pelaksana, 30 orang berlatar belakang pendidikan SI, 13 orang orang Diploma 3 (D3) dan 2l orang SMA sederajat. Apabila di presentasikan maka aparatur yang memiliki latar belakang pendidikan SI Hampir mencapai 50\%, D3 I5\% dan SMA sederajat 35\%. Hal ini sesuai dengan pernyataan kepala bidang aset BPKAD Kota Palangka Raya.

b. Informasi 
Informasi mengenai cara melaksanakan

kebijakan telah jelas dilakukan oleh

Pemerintah Kota Palangka Raya melalui

sosialisasi dan juga bimbingan teknis

sebagimana yang telah diungkapkan Kepala

Bidang Aset BPKAD Kota Palangka Raya.

c. Fasilitas

Fasilitas fisik merupakan faktor penting dalam impelementasi kebijakan. Implementor mungkin mempunyai staf yang mencukupi kapabel dan kompeten, tetapi tanpa adanya fasilitas pendukung (sarana dan Prasarana) maka implementasi kebijakan tersebut tidak akan berhasil.

4. Struktur Birokrasi

Pasa umumnya semakin besar koordinasi yang diperlukan untuk melaksanakan kebijakan, semakin berkurang kemungkuinan keberhasilan program atau kebijaka.

Mengingat struktur birokrasi di pemerintah Kota Palangka Raya yang memerlukan koordinasi cukup banyak maka dapat dikatakan bahwa kemungkinan keberhasilan kebijakan akan berkurang.

Banyaknya kasus bawa pakai kendaraan operasional milik daerah dapat dikarenakan oleh lemahnya pengawasan dan pengendalian oleh pemegang otoritas pengelolaan sehingga berakibat kerancuan dn ketidakberdayaan ditataran pelaksana kebijakan dalam melaksankaan tugasnya.

\section{KESIMPULAN}

Berdasarkan hasil penelitian dan pembahasan dapat disimpulkan bahwa implementasi kebijakan pengelolaan inventaris bergerak milik Kota Palangka Raya belum berjalan sebagaimana mestinya yang dominan disebabkan/dipengaruhi oleh faktor komunikasi, dan disposisi. Sementara faktor sumber daya dan struktur birokrasi juga berperan namun tidak dominan. Pelanggaran terhadap kebijakan tentang pegelolaan inventaris Barang Bergerak Milik Daerah yang paling sering terjadi adalah barang bergerak milik daerah Kota Palangka Raya dibawa pakai tanpa prosedur seharusnya baik saat mutasi ataupun saat purna tugas. Sehingga Saran yang dapat diberikan pada kesempatan ini adalah :

I. Diharapkan agar para Kepala Badan/Dinas dapat menjalin komunikasi yang solid dan up to date sehingga impelementasi kebijakan pengelolaan inventaris bergerak milik daerah kota Palangka Raya dapat berjalan dengan baik.

2. Diharapkan agar pejabat penguasa bisa memberikan sanksi tegas kepada PNS dan tidak memberikan toleransi terhadap berbagai alasan mengenai pinjam pakai barang inventaris yang tidak prosendural, membawa barang inventaris yang masih dalam usul proses DUM/Penjualan bagi PNS yang sudah purna tugas dan PNS masih aktif yang bisa menghambat kelancaran tugas pokok dan fungsi jalannya pemerintah Kota Palangka Raya.

3. Diharapkan agar pemerintah Kota Palangka Raya dapat menambah anggota petugas/penyimpanan barang dalam rangka tercapainya implementasi kebijakan yang baik dan lancar.

4. Diharapkan agar dinas terkait bisa meningkatkan intensitas bimbingan teknis yang efektof dan efesien serta meningkatkan koordinasi antar birokrasi sehingga implementasi dapat berjalan lancar.

\section{REFERENSI}

Andrianingsih S. 2008. Impelementasi Kebijakan Jakarta : FISIP UI

Arikunto, S. 2005. Manajemen Penelitian. Jakarta. Rineka Cipta

Burhan Bungin. 2010. Metodologi Penelitian Kualitatif. Jakarta : Kencana

Burhan Bungin. 2010. Analisis Data Penelitian Kulitatif. Jakarta : Kencana 
Chabib Soleh dan Heru Rocmasjah. 2007. Pengelolaan Keuangan dan Aset Daerah Sebuah pendekatan Struktural menuju Tata Kelola Pemerintahan yang baik. Bandung : Fokus Media

Dolil.D.Siregar. Manajemen Aset. Jakarta : Gramedia Pustaka Utama

Dwidjiwijota. 2006. Kebijakan Publik untuk NegaraNegara berkembang. Jakarta : PT Elex Media Komputindo

Handayani L. 2002. Implementasi Kebijakan Penetapan Upah Minimum Kabupaten (Study Kasus di Kecamatan Sayung Kabupaten Demak). Semarang : Universitas Diponegoro

Iskandar. 2008. Metodologi Penelitian Pendidikan dan Sosial (Kuantitatif dan Kualitatif). Jakarta : Gaungh Persada Press (GP Press)

Muchtar,Hidayat. 2012. Manajemen Aset Privat dan Publik. Yogyakarta : PRESSindo

Nugroho, R. 2008. Public Policy. Jakarta : PT Elex Media Komputindo

Puji, Agus. 20II. Manajemen Barang Daerah. Bandung

Peraturan Pemerintah Nomor 6 Tahun 2006 Tentang Pengelolaan Barang Milik Negara/Daerah

Peraturan Menteri dalam negeri nomor 17 tahun 2007 tentang pedoman teknis pengelolaan barang milik daerah. Bandung : Fokus Media Cetak Kedua

Peraturahn Pemerintah Dalam Negeri Nomor 38 Tahun 2008 tentang pengelolaan Aset Daerah. 